Military Technical College

Kobry El-Kobbah, Cairo, Egypt

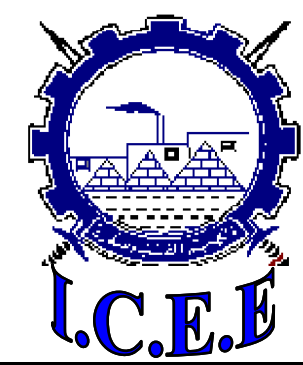

$5^{\text {th }}$ International Conference on

Chemical \& Environmental

Engineering

25 - 27 May, 2010.

\title{
EE-1 \\ STUDIES FOR REMOVAL OF CYANIDE AND ORGANIC COMPOUNDS FROM INDUSTRIAL WASTEWATER USING THE FENTON AND FENTON LIKE TECHNIQUES
}

\author{
Ashour M. M. Awad ${ }^{*}$, Montaser Y. Ghaly ${ }^{* *}$ and Mohammad Z. Abdel Wahhab ${ }^{* * *}$
}

\begin{abstract}
Removal of the organic load, cyanides and lubricating oils, from liquid effluents of a specific chemical industry is investigated, where the wastewater is characterised by a high value of the chemical oxygen demand (COD) and high content of oils and cyanides. Such an effluent is usually treated by the (coagulation/chlorination) technique which has numerous disadvantages, of which the cyanogen chloride evolution and the possible leakage of chlorine are known to be very dangerous for human being. In the present work the Fenton and Fenton - like processes were employed to remove the majority of organic matters, cyanides and oils. Experimental tests were conducted to determine the effectiveness and the optimum operating conditions for wastewaters. The treatment train was found to be capable of lowering the wastewater (COD) from $16660 \mathrm{mg} / \mathrm{l}$ to $333 \mathrm{mg} / \mathrm{l}$ by the Fenton process and to $800 \mathrm{mg} / \mathrm{l}$ by the Fenton-like one, Cyanides from $9.11 \mathrm{mg} / \mathrm{l}$ to $0.18 \mathrm{mg} / \mathrm{l}$ and to $1.17 \mathrm{mg} / \mathrm{l}$, and oils from 32910 $\mathrm{mg} / \mathrm{l}$ to $65.82 \mathrm{mg} / \mathrm{l}$ by using both methods. Kinetic studies showed that the reaction is first order for COD measurements and cyanide removal. The ratios of $\mathrm{BOD}_{5} / \mathrm{COD}$ values obtained indicate that both Fenton and Fenton like treatments can enhance the biological treatment since they can convert the pollutants to easily biodegraded compounds. Results proved that the Fenton process is much better than the currently used methods because of its safety, efficiency and low comparative costs.
\end{abstract}

\section{Keywords}

Wastewater, Cyanide Removal, oil Removal, COD, Fenton process.

* Massara for engineering industries, Helwan, Cairo.Egypt.

** Dept. of chemical engineering and pilot plant, NRC, Cairo ,Egypt

*** Dept. of chemical engineering, Fac. of engineering, Minia University, Cairo. Egypt. 


\section{INTRODUCTION}

Many industrial operations produce wastewater which is to be either circulated or drained to the environment. Wastewater from industrial units can be classified as to be either domestic wastewaters or process wastewaters. Within the scope of the present investigation, the process liquid effluents of an electroplating plant was audited due to the lack of efficient treatment procedures to meet with the high organic loads and cyanide content of such an effluent.

In the production sectors of such industry, the electroplating processes for ferrous and non ferrous metals are carried out. Oils and greases are removed from objects to be electroplated (the tools) using solvent and then tools are put in a detergent. The tools are immersed in hydrochloric acid for a time and then washed by nitric and sulphuric acids (a pickling process). Electroplating can be then carried out where the tools are covered with nickel, copper or chromium, using salts of these metals which contain cyanides. Detergents used for cleaning small tools are mixed with sodium cyanide for some technical reasons. Heat treatments of metals are carried out using sodium cyanide and for quenching purposes oils are used. Sulphuric acid, cyanides, detergents and phosphate compounds are used to phosphatize the ferrous metals. Electroplating of small parts of ferrous metals use nickel salts which contain cyanides. Numerous types of oils and greases are of course generated from the transportation means and maintenance sectors in that industrial factory.

Cyanides are highly toxic, their poisonous effect is rapid in action. When these compounds are inhaled or ingested, their physiological effect involves an inactivation of the respiratory enzymes, preventing tissue utilization of the oxygen carried by the blood. Industrial oils such as lubricating and hydraulic pressure fluids that are used to lubricate steel sheets to reduce rusting are of high level of toxic organic contaminants which cause several environmental pollutions. The effluents from that company, for example, contain industrial and domestic wastewaters, which contain oils, cyanides and traces of heavy metals which are to be treated to meet with the requirements of the environmental. The current treatment method consists of coagulation with ferric chloride as a first step combined with a chlorination step. Analysis of the outlet stream revealed that, the cyanide content was higher than the local Egyptian Environmental requirements, in addition, leakage of chlorine from the chlorination units which is highly dangerous and inevitable, was detected. Chlorine is highly toxic via inhalation, and is of intense irritation of the respiratory system, skin and eyes. Sufficient concentration of the gas irritates the mucous membranes, it can cause pulmonary edema. Liquid chlorine in contact with skin causes frostbite smarting of the skin. Vapors will cause severe irritation of eyes and throat and can cause eye and lung injury, moreover, the chlorination units are very expensive. Another disadvantage of this method is the poisonous effect of cyanogen chloride, which evolves when a waste containing concentrated cyanides is treated directly by this method The Fenton (FP) and Fenton-like (FLP) processes used in the present study proved to be better than the coagulation/chlorination method with respect to its higher efficiency, safe procedures and acceptable results.

\section{Materials}

Due to the real industrial nature of the present investigation, all experimental procedures were carried by laboratory means and the results were actually tested on an industrial scale using an already operating system. Preliminary experiments were carried out to choose the best laboratory operating conditions. The materials used for testing were: Sodium cyanide; $98.5 \%$ purity, Sodium hydroxide; 99\% purity, Copper ion samples; mixture of copper cyanide, 
sodium cyanide and sodium hydroxide, Chromium ion samples; mixtures of potassium dichromate and sodium hydroxide, Nickel ion samples; mixture of nickel sulphate, boric acid and sodium hydroxide. (Where $\mathrm{Cu}, \mathrm{Cr}$ and $\mathrm{Ni}$ mixtures represent the heavy metals in the real wastewater); Simulating oils (Lubricant oils, hydraulic oils, cooling oils, cut oils and quenching oils were obtained from Misr Co., Co - operation, Co., Exon Mobil Co. and Caltex Co., Cairo, Egypt., Sulphuric acid, 95 - $97 \%$ purity, $1.84 \mathrm{~g} / \mathrm{cm}^{3}$ density. used for adjusting $\mathrm{pH}, \mathrm{FeSO}_{4} .7 \mathrm{H}_{2} \mathrm{O} ; 99 \%$ purity, $\mathrm{FeCl}_{3} .6 \mathrm{H}_{2} \mathrm{O} ; 99 \%$ purity, $\mathrm{H}_{2} \mathrm{O}_{2} ; 30 \%, 1.15$ $\mathrm{g} / \mathrm{cm}^{3}$ density, Sodium hypochlorite, $15 \%$ available chlorine, Sodium bicarbonate, $99 \%$ purity, $\mathrm{Fe}_{2}\left(\mathrm{SO}_{4}\right)_{3} ; 65$ to $75 \%$ purity.

The diversity of the wastewater obtained from that industry considered, due - of course - to the diverse operations and treatments, samples of the wastewater were carefully followed - up and collected over chosen periodical periods of times conforming with the diversity of industrial operations carried out. Table 1 shows the average characteristics of the real industrial wastewater collected at different periods of times aiming to attain representatives annual averages for the whole operations.

\title{
3. Experimental
}

To begin an experiment, $250 \mathrm{ml}$ of the real wastewater is put in a $400 \mathrm{ml}$ beaker fitted with a magnetic stirrer, where the $\mathrm{pH}$ is adjusted to 3 by $\mathrm{H}_{2} \mathrm{SO}_{4}$. The amount of reagent (either $\mathrm{FeSO}_{4} .7 \mathrm{H}_{2} \mathrm{O}$ (FP) or $\mathrm{FeCl}_{3} \cdot 6 \mathrm{H}_{2} \mathrm{O}$ (FLP)) designed for the experiment is added and homogenized by the stirrer. The designed amount of $\mathrm{H}_{2} \mathrm{O}_{2}$ is added. One hour stirring was found by preliminary studies to be sufficient for completion of treatment. Excess $\mathrm{H}_{2} \mathrm{O}_{2}$ is then removed by adding drops of sodium hydroxide for neutralization and to prevent interference with the results of sample analysis for the COD content and absorbance measurements. The $\mathrm{pH}$ of the sample is adjusted at 7 to 10 and allowed to settle overnight [1]. After filteration, the filterate is tested for its COD and cyanide values.

\begin{abstract}
ANALYSIS
COD and cyanide were analyzed according to standard examination methods of water and wastewater (1995) [2] by a calibrated Shimadzue spectrophotometer (Model UV - 120 - 02), $\mathrm{H}_{2} \mathrm{O}_{2}$ was determined by iodometric titration $[3,4], \mathrm{pH}$ measurements were carried out by pH meter CG 810 GMBH D 6238 HOFHEIM/TS - POSTFACH 1130, Heavy metals (Ni,Cr,Cu.) were determined with Nanocolor meter MACHEREY-NAGAL.GmbH \& Co.KE Postfach 101352 D - 52313 DUEREN. Total suspended solids (T.S.S), oils and greases and $\mathrm{BOD}_{5}$ analyses were determined according to standard methods of examinations. The total organic carbon (TOC) was determined by the potassium permangnate method $[5,6]$.
\end{abstract}

\section{Results and discussion}

\subsection{Effect of $\mathrm{H}_{2} \mathrm{O}_{2}$ Concentration}

Experiments were thus carried out using real wastewater and up to $32 \mathrm{ml} / 1 \mathrm{H}_{2} \mathrm{O}_{2}$ and $\mathrm{Fe}^{2+}$ of $402 \mathrm{mg} / \mathrm{l}$. The experimental results showed that the remaining amounts of iron and $\mathrm{H}_{2} \mathrm{O}_{2}$ by Fenton process were high. As can be seen from Figure 1 the removal of cyanide decreased and the values of COD were nearly constant for values after $2 \mathrm{ml} / 1 \mathrm{H}_{2} \mathrm{O}_{2}$, which may be attributed to the fact that the high amounts of $\mathrm{H}_{2} \mathrm{O}_{2}$ and iron act as scavengers for $\mathrm{OH}^{*}$ generating during the reaction between $\mathrm{H}_{2} \mathrm{O}_{2}$ and iron according to the following reactions $[7,8]$. 


$$
\begin{aligned}
& \mathrm{Fe}^{2+}+\mathrm{OH}^{\bullet} \rightarrow \mathrm{Fe}^{3+}+\mathrm{OH}^{-} \\
& \mathrm{H}_{2} \mathrm{O}_{2}+\mathrm{OH}^{\bullet} \rightarrow \mathrm{HO}_{2}+\mathrm{H}_{2} \mathrm{O} \\
& \mathrm{HO}_{2}+\mathrm{OH}^{\bullet} \rightarrow \mathrm{H}_{2} \mathrm{O}+\mathrm{O}_{2} \\
& \mathrm{OH}^{\bullet}+\mathrm{OH}^{\bullet} \rightarrow \mathrm{H}_{2} \mathrm{O}_{2}
\end{aligned}
$$

The optimum amount of $\mathrm{H}_{2} \mathrm{O}_{2}$ is thus about $2 \mathrm{ml} / \mathrm{l}$ as shown in Figure 1 where the removal of COD and cyanide was 93 and $71 \%$, respectively. Thus experiments were carried out using up to $2.5 \mathrm{ml} / 1 \mathrm{H}_{2} \mathrm{O}_{2}$ for both FP and FLP and $100 \mathrm{mg} / \mathrm{l}$ of $\mathrm{FeSO}_{4} .7 \mathrm{H}_{2} \mathrm{O}\left(20 \mathrm{mg} / \mathrm{l} \mathrm{Fe}{ }^{2+}\right.$, FP) as shown in Figure 2 and $100 \mathrm{mg} / 1 \mathrm{FeCl}_{3} .6 \mathrm{H}_{2} \mathrm{O}\left(20.7 \mathrm{mg} / \mathrm{l} \mathrm{Fe}{ }^{3+}, \mathrm{FLP}\right)$ as shown in Figure 3. Figure 2 shows that the COD and cyanide removals increase with increasing $\mathrm{H}_{2} \mathrm{O}_{2}$ until $1 \mathrm{ml} / 1$ which is due to the generation of $\mathrm{OH}^{\bullet}$ during the reaction of $\mathrm{FeSO}_{4} .7 \mathrm{H}_{2} \mathrm{O}$ with $\mathrm{H}_{2} \mathrm{O}_{2}$. The removal then decreases, because the excess $\mathrm{H}_{2} \mathrm{O}_{2}$ scavenges the $\mathrm{OH}^{*}$. The COD reduction attained $92 \%$ while cyanide removal was $73 \%$ at $1 \mathrm{ml} / 1 \mathrm{H}_{2} \mathrm{O}_{2}$. Figure 3 on the other hand shows a COD reduction of $80 \%$ and a cyanide removal of $60 \%$ at $\mathrm{H}_{2} \mathrm{O}_{2}$ concentration of $1 \mathrm{ml} / \mathrm{l}$. The optimum operating $\mathrm{H}_{2} \mathrm{O}_{2}$ concentration is thus about $1 \mathrm{ml} / \mathrm{l}$ for the wastewater by both methods, FP and FLP.

\subsection{Rate of $\mathrm{H}_{2} \mathrm{O}_{2}$ Consumption}

Figure 4 shows that the concentration of $\mathrm{H}_{2} \mathrm{O}_{2}$ at $25^{\circ} \mathrm{C}$ decreases from $1 \mathrm{ml} / 1$ to $0.156 \mathrm{ml} / \mathrm{l}$ by the Fenton process and to $0.34 \mathrm{ml} / \mathrm{l}$ by the Fenton - like (after 7 minutes), where $\mathrm{H}_{2} \mathrm{O}_{2}$ reacts with $\mathrm{Fe}^{2+}$ or $\mathrm{Fe}^{3+}$ very quickly at first and continue to decrease from $0.156 \mathrm{ml} / 1$ to nearly nil for Fenton and to $0.156 \mathrm{ml} / 1$ for Fenton-like process at the end of the reaction (after 240 minutes). Figure 5 on the other hand shows that the concentration of $\mathrm{H}_{2} \mathrm{O}_{2}$ at $45^{\mathrm{O}} \mathrm{C}$, decreases within 15 minutes from $1 \mathrm{ml} / 1$ to $0.15 \mathrm{ml} / 1$ by the Fenton process and to $0.17 \mathrm{ml} / 1$ by the Fenton-like, where $\mathrm{H}_{2} \mathrm{O}_{2}$ reacts with $\mathrm{Fe}^{2+}$ or $\mathrm{Fe}^{3+}$ very quickly at first and decreases to be nil for Fenton and Fenton-like processes after 180 minutes and 120 minutes of reaction, respectively.

\subsection{Effect of $\mathrm{Fe}^{2+}$ or $\mathrm{Fe}^{3+}$ concentration}

Oxidation by $\mathrm{H}_{2} \mathrm{O}_{2}$ alone is not effective for high concentrations of certain refractory contaminants, such as highly chlorinated aromatic compounds and inorganic compounds such as cyanides, because of the low rates of reaction at reasonable $\mathrm{H}_{2} \mathrm{O}_{2}$ concentrations. Transition metal salts (e.g. iron salts), ozone and UV- light can activate $\mathrm{H}_{2} \mathrm{O}_{2}$ to form hydroxyl radicals which are strong oxidants [9].

When the added amount of $\mathrm{Fe}^{2+}$ increases, the elimination rate of pollutants increases as well [10]. However, when $\mathrm{Fe}^{2+}$ is overdosed, the hydroxyl radicals are scavenged as shown in the mechanism by equation (1) [7].

The effect of $\mathrm{Fe}^{2+}$ concentration on removal efficiencies for real wastewater by Fenton process is given in Figure 6 which shows that the maximum COD reduction is $92 \%$ by using $100 \mathrm{mg} / 1 \mathrm{FeSO}_{4} .7 \mathrm{H}_{2} \mathrm{O}\left(20 \mathrm{mg} / 1 \mathrm{Fe}^{2+}\right)$ and $1 \mathrm{ml} / 1 \mathrm{H}_{2} \mathrm{O}_{2}$ where $\mathrm{pH}$ and temperature are kept at 3 and $25^{\mathrm{O}} \mathrm{C}$, respectively. At the same time $73 \%$ of cyanide content was removed. The effect of the dose of $\mathrm{FeCl}_{3} \cdot 6 \mathrm{H}_{2} \mathrm{O}$ on the $\mathrm{COD}$ value and cyanide removal efficiency by Fenton-like process has been studied and the results are shown in Figure 7. The maximum COD reduction is $80 \%$ by using $100 \mathrm{mg} / \mathrm{l} \mathrm{FeCl} 3 \cdot 6 \mathrm{H}_{2} \mathrm{O}\left(20.7 \mathrm{mg} / \mathrm{l} \mathrm{Fe}{ }^{3+}\right)$ and $1 \mathrm{ml} / 1 \mathrm{H}_{2} \mathrm{O}_{2}$ where $\mathrm{pH}$ and temperature are kept at 3 and $25^{\circ} \mathrm{C}$, respectively. At the same time $60 \%$ of cyanide removal was obtained. The $\mathrm{Fe}^{3+}$ formed can be expectd to react with $\mathrm{H}_{2} \mathrm{O}_{2}$ as well as with hydroperoxy 
radicals $\left(\mathrm{HO}_{2}^{\circ}\right)$ with regeneration of $\mathrm{Fe}^{2+}$ in the solution resulting in a decrease in COD value, as shown in equation 5 and 6 [9] .

$$
\begin{aligned}
& \mathrm{Fe}^{3+}+\mathrm{H}_{2} \mathrm{O}_{2} \rightarrow \mathrm{Fe}^{2+}+\mathrm{H}^{+}+\mathrm{HO}_{2}^{\cdot} \\
& \mathrm{Fe}^{3+}+\mathrm{HO}_{2}^{\circ} \rightarrow \mathrm{Fe}^{2+}+\mathrm{O}_{2}+\mathrm{H}^{+}
\end{aligned}
$$

Figures 6 and 7 show that the COD value and cyanide removal efficiency started to decrease after a dose of $100 \mathrm{mg} / \mathrm{l}$ of $\mathrm{FeSO}_{4} .7 \mathrm{H}_{2} \mathrm{O}$ and $\mathrm{FeCl}_{3} \cdot 6 \mathrm{H}_{2} \mathrm{O}$ (i.e $20 \mathrm{mg} / \mathrm{l} \mathrm{Fe} \mathrm{F}^{2+}$ and $20.7 \mathrm{mg} / \mathrm{l}$ $\mathrm{Fe}^{3+}$ ). This may be explained by the redox reactions also since $\mathrm{OH}^{\cdot}$ may be scavenged by the reaction with the $\mathrm{H}_{2} \mathrm{O}_{2}$ or with another $\mathrm{Fe}^{2+}$ molecules as shown before ${ }^{(7,8)}$ in equations (1 to 4).

\subsection{Effect of acidity of the medium}

Real wastewater was treated by the Fenton process to determine the optimum $\mathrm{pH}$ as illustrated in Figure 8. About 92\% COD decrease and $73 \%$ cyanide removal were obtained at $\mathrm{pH} 3$ whereas the $\mathrm{H}_{2} \mathrm{O}_{2}$ concentration was $1 \mathrm{ml} / \mathrm{l}$ with $100 \mathrm{mg} / \mathrm{l}$ of $\mathrm{FeSO}_{4} \cdot 7 \mathrm{H}_{2} \mathrm{O}$. By the Fenton-like process the optimum $\mathrm{pH}$ was determined, by changing $\mathrm{pH}$ value between 1 and 5 as illustrated in Figure 9. About $80 \% \mathrm{COD}$ and $60 \%$ cyanide removals were obtained at $\mathrm{pH}=3$ and at $\mathrm{H}_{2} \mathrm{O}_{2}$ concentration of $1 \mathrm{ml} / \mathrm{l}$ with $\mathrm{FeCl}_{3} .6 \mathrm{H}_{2} \mathrm{O}$ at $100 \mathrm{mg} / \mathrm{l}$. The drop in efficiency at high $\mathrm{pH}$ values in $\mathrm{COD}$ and cyanide removals may be attributed to the precipitation of $\mathrm{Fe}(\mathrm{OH})_{3}$. In this form, iron decomposes $\mathrm{H}_{2} \mathrm{O}_{2}$ into oxygen and water and consequently the oxidation rate decreases because less hydroxyl radicals are available [11]. On the other hand, at very low $\mathrm{pH}$ values the reaction may be inhibited where less amount of $\mathrm{OH}^{*}$ is present due to the scavenging effect of the hydrogen ion as shown in equation (7) [8].

$\mathrm{OH}^{\cdot}+\mathrm{H}^{+}+\mathrm{e}^{-} \rightarrow \mathrm{H}_{2} \mathrm{O}$

\subsection{Effect of Temperature}

Figure 10, shows the COD and cyanide removal efficiencies for the real wastewater from $20^{\circ} \mathrm{C}$ to $65^{\circ} \mathrm{C}$ by the Fenton process where the COD reduction changes from $70 \%$ at $20^{\circ} \mathrm{C}$ to $75 \%$ at $65^{\circ} \mathrm{C}$. The cyanide removal, on the other hand, changes from $37.5 \%$ at $20^{\circ} \mathrm{C}$ to $51 \%$ at $65^{\circ} \mathrm{C}$. Figure 11 shows the trend by the Fenton- Like process where the COD reduction changes from $57.5 \%$ at $20^{\circ} \mathrm{C}$ to $80 \%$ at $65^{\circ} \mathrm{C}$, where the cyanide removal hanges from $25 \%$ at $20^{\circ} \mathrm{C}$ to $34 \%$ at $65^{\circ} \mathrm{C}$. It can be concluded that, the removal efficiencies for COD and cyanide is the highest at $45^{\circ} \mathrm{C}$ but for higher temperatures they are lower. At lower temperatures the reaction rate is expected to be slower and at higher temperatures the $\mathrm{H}_{2} \mathrm{O}_{2}$ decomposes into oxygen and water. This agrees with some findings in literature [1,11], where the destabilization of flocs results in an increase in ferrous ions, which scavenges the $\mathrm{OH}^{*}$ during the Fenton's reaction $[7,8]$. The rapid $\mathrm{H}_{2} \mathrm{O}_{2}$ decomposition at high temperatures is a common behavior in the Fenton process [12].

\subsection{Effect of presence of Excess $\mathrm{H}_{2} \mathrm{O}_{2}$}

Figure (12) shows the effect of neutralization of a sample of wastewater after treatment by the Fenton and the Fenton-like processes on the COD and cyanide analysis. Sodium hydroxide was added to remove the residual $\mathrm{H}_{2} \mathrm{O}_{2}$ which may interfere with wastewater analyses till neutralization. Results show that the neutralization gave better results for removals. The COD reduction percentage has increased by about $13.15 \%$ while the cyanide removal by about $36 \%$ for the Fenton process, by the Fenton - like process, on the other hand, an increase of $23.8 \%$ for COD reduction analysis and about $35 \%$ increase for the cyanide analysis was attained. 
These findings can be interpreted by the fact that after treatment by the Fenton or the Fentonlike processes, highly insoluble $\mathrm{Fe}(\mathrm{OH})_{3}$ forms in equilibrium with iron salts in solution, to give a flocculent precipitate which facilitates the separation of suspended materials such as domestic wastes and oils in effluent and so reducing the COD. Also, this treatment can reduce the dissolved compounds by adsorption onto the ferric gel [13]. As a result, both the COD reduction and cyanide removal will gain higher values.

\subsection{Effect of Stirring}

Figure 13 shows the effect of stirring speeds on COD and cyanide removals for real wastewater. The COD reduction efficiency by the Fenton process at $(70 \mathrm{rpm})$ is $92 \%$, at (170 $\mathrm{rpm})$ is $60.16 \%$ and at $(300 \mathrm{rpm})$ is $58 \%$. The cyanide removal efficiency at (70 rpm) on the other hand is $73 \%$, at $(170 \mathrm{rpm})$ is $62 \%$, at $(300 \mathrm{rpm})$ is $37 \%$. By the Fenton - like process COD reduction efficiency at $(70 \mathrm{rpm})$ is $80 \%$, at $(170 \mathrm{rpm})$ is $62.8 \%$ and at $(300 \mathrm{rpm})$ is $49.5 \%$. From these results it can be concluded that the low speed $(70 \mathrm{rpm}$.) is the best for the reaction results in between the three speeds tested, these results agree with literature findings $[14,15]$. This is perhabs due to the better steady state conditions given by low speed agitation and thus the resulting stream line actions far from turbulance which may accelerate the deterioration of some of the hydrogen peroxide reactant.

\subsection{Effect of Catalyst Type}

Figure 14 shows that the COD reduction efficiency is in the order $\mathrm{Fe}_{2}\left(\mathrm{SO}_{4}\right)_{3}=\mathrm{FeSO}_{4}>\mathrm{FeCl}_{3}$ and that it is the same for the cyanide removal efficiency. From literature ${ }^{(16)}$, it was sited that, the presence of chloride ions in wastewater might act as a scavenger for hydroxyl radicals, thus decreasing the organic matter degradation. Also the $\mathrm{Fe}^{3+}$ react with $\mathrm{H}_{2} \mathrm{O}_{2}$ producing $\mathrm{HO}_{2}{ }_{2}$ with regeneration of $\mathrm{Fe}^{2+}$ in the solution. The $\mathrm{HO}_{2}^{\circ}$ formed is relatively non-reactive with organic matter, being of lower oxidation capability than the $\mathrm{OH}^{*}$ resulting in decrease in COD reduction.

\subsection{Effect of Scavenging Elements}

Figures 15 shows that the COD and cyanide removals decreased in presence of $\mathrm{HCO}_{3}{ }^{-}$ions due to the $\mathrm{OH}^{*}$ scavenging characteristics of $\mathrm{HCO}_{3}{ }^{-}$by reacting with the free $\mathrm{OH}^{-}$as in reaction (8). The carbonate radicals $\left(\mathrm{CO}_{3}{ }^{-\bullet}\right)$ formed could then react with $\mathrm{H}_{2} \mathrm{O}_{2}$ to form $\mathrm{HO}_{2}{ }^{\circ}$ (reaction 9). Both $\mathrm{H}_{2} \mathrm{O}_{2}$ and $\mathrm{HO}_{2}{ }^{\circ}$ are intermediate species with less oxidation potentials compared to the free hydroxyl radical. The presence of bicarbonate ions in water, thus, consumes the radicals and consequently decreases the oxidation rate of organics and cyanide.

$$
\begin{aligned}
& \mathrm{OH}^{\bullet}+\mathrm{HCO}_{3}^{-} \rightarrow \mathrm{CO}_{3}^{-\bullet}+\mathrm{H}_{2} \mathrm{O} \\
& \mathrm{CO}_{3}^{-\bullet}+\mathrm{H}_{2} \mathrm{O}_{2} \rightarrow \mathrm{HO}_{2}{ }^{-}+\mathrm{HCO}_{3}^{-}
\end{aligned}
$$

\section{BIODEGRADIBILITY OF THE TREATED WASTEWATER:}

The ratio of $\mathrm{BOD}_{5} / \mathrm{COD}$ in wastewater is normally used to express the biodegradability of the wastewater. When the ratio of $\mathrm{BOD}_{5} / \mathrm{COD}$ is more than 0.3 , the wastewater has a better biodegradability, whereas if that ratio is less than 0.3 , the wastewater is considered as difficult to be biodegraded $[1,17,18]$.

The ratio of $\mathrm{BOD}_{5} / \mathrm{COD}$ of the wastewater under study is 0.15 before treatments and thus it can't be treated biologically, indicating that, wastewater containing cyanide and organic compounds (in the form of oils) inhibits the respiratory activity of bacterial seed due to their toxicity. After Fenton and Fenton - like treatments, the ratio of $\mathrm{BOD}_{5} / \mathrm{COD}$ became 0.6 and 
0.3 , respectively. These ratios indicate that both Fenton and Fenton-like treatments can enhance the biological treatment since they can convert the pollutants present in the wastewater to be easily biodegraded, they can be used as pretreatment steps accompanied by biological treatments, since the values of the ratios of $\mathrm{BOD}_{5} / \mathrm{COD}$ are equal to or higher than 0.3 . A decrease in treatment costs can also be achieved by short reaction times and by using fewer chemicals.

\section{AN APPROACH TO KINETIC STUDIES:}

1. Time - Temperature Relations:

At $25^{\circ} \mathrm{C}, 98.77 \%$ for COD and $97.8 \%$ for cyanide were obtained by the Fenton process while by the Fenton-like, the results were $95.5 \%$ for COD and $85.86 \%$ for cyanide removals. At $45^{\circ} \mathrm{C}$ the values were $99.3 \%$ for COD and $97.8 \%$ for cyanide by the Fenton process, while being $97 \%$ for COD and $84.8 \%$ for cyanide by the Fenton-like process.

At the beginning of the reaction the results obtained at $45^{\circ} \mathrm{C}$ were better than the results at $25^{\mathrm{O}} \mathrm{C}$, while at the end of the reaction the removal efficiency for both two temperatures are nearly the same. Thus, operation at room temperature will be much more acceptable from an economic and operating point of views, for a maximum time of 300 minutes.

\section{Kinetic Estimations:}

Figures 16 to 19 show the relation between time and logarithmic concentration ratios at different agitation speeds. The plots show straight line relations and the results agree with a first order reaction kinetics for both COD nd cyanide treatments by both techniques; Fenton and Fenton-like processes. The following relation (10)

$$
\ln \mathrm{C}_{\mathrm{t}} / \mathrm{C}_{0}=-\mathrm{K}_{0} \mathrm{t}
$$

applies thus to both COD and Cyanide treatments, where $\mathrm{C}_{\mathrm{O}}$ and $\mathrm{C}_{\mathrm{t}}$ are the rations $(\mathrm{mg} / \mathrm{l})$ at zero and (t) time intervals and $\mathrm{K}_{0}$ is a first-order rate stant $\left(\mathrm{min}^{-1}\right)$. Figure 20 shows the relation between $\log \mathrm{K}_{\mathrm{o}}$ and $\log$ (agitation speed) for COD treatments by the Fenton and Fenton-like processes. It can be seen that $\log \mathrm{K}_{0}$ decreases with increasing log rpm and that the straight line corresponding to the Fenton process is higher than that for the Fenton-like process. Figure 21, on the other hand, shows the relation between $\log \mathrm{K}_{\mathrm{O}}$ and $\log$ (agitation speed) for the removal of cyanide by both the Fenton and the Fenton-like processes. It can be observed also that $\log \mathrm{K}_{0}$ decreases with increasing of $\log (\mathrm{rpm})$; thus the same discussion above can be applied.

\section{AN APPROXIMATE COMPARATIVE LOCAL COST ESTIMATION:}

From experiments it was known that the initial COD was $16660 \mathrm{mg} / \mathrm{l}$, the amount of $\mathrm{H}_{2} \mathrm{O}_{2}=$ $1 \mathrm{ml} / \mathrm{l}$. and ferrous sulphate was $100 \mathrm{mg} / \mathrm{l}$. The average value of CODo wastewater for 6 months was caculated to be $2000 \mathrm{mg} / \mathrm{l}$.

Chemicals were used in wastewater treatment according to COD values. If COD is $2000 \mathrm{mg} / \mathrm{l}$, $\mathrm{H}_{2} \mathrm{O}_{2}$ needed was $0.12 \mathrm{ml} / \mathrm{l}(138 \mathrm{mg} / \mathrm{l}), \mathrm{FeSO}_{4} .7 \mathrm{H}_{2} \mathrm{O}$ is $12 \mathrm{mg} / \mathrm{l}, \mathrm{H}_{2} \mathrm{SO}_{4}$ is $300 \mathrm{mg} / \mathrm{l}$ and $\mathrm{Na}_{2} \mathrm{CO}_{3}$ is $200 \mathrm{mg} / \mathrm{l}$.

For achieving 99\% COD reduction and $98 \%$ cyanide removal by the Fenton process the total cost estimated was about $0.741 \mathrm{LE} / \mathrm{m}^{3}$ real wastewater in comparison to $0.981 \mathrm{LE} / \mathrm{m}^{3}$ real 
wastewater for achieving 93\% COD measurement and $94 \%$ cyanide removal by the traditional method which shows an economic benefit besides the other technical and safety advantages discussed before.

\section{Conclusion}

As discussed before the efficiency and safety of the Fenton process are higher than those for the coagulation / chlorination method, also the costs of the novel processes are estimated to be lower than that for the coagulation / chlorination method. It is thus of importance to consider the Fenton process as the better treatment method for the real industrially produced cyanide wastewater. This is encouraged by two points of view; the first of which is the simplicity of its application accompanied by its lower costs, and the second, is its sustainable friendship to environmental impacts. The chemicals and operating conditions of the Fenton process have the least (or no) corrosion behavior; this elongates the life operating time of equipment, as compared to the conditions of the traditional methods using chlorine and chlorides. Kinetic studies proved that both the Fenton and Fenton-like processes can be expressed by the simple first-order reaction for both COD changes and cyanide removals. The ratio $\left(\mathrm{BOD}_{5} / \mathrm{COD}\right)$ were found to be of about 0.6 and 0.3 maximum values for real effluent by novel methods Fenton and Fenton - Like treatments compare to 0.12 and 0.15 values before treatments. These ratios indicate that both Fenton and Fenton - Like treatment can enhance the biological treatment since they can convert the pollutants present in the wastewater to be easily biodegraded, which gives an additional benefit for these novel techniques.

\section{REFERENCES}

[1] Anabela, M., Guedes, M., Luis, M., "Fenton oxidation of cork cooking wastewater", Water Research, 37, 3061-3069, 2003.

[2] Andrew, D., Lenore, S. and Arnold, E., Standard methods for the examination of water and wastewater, 19th edition, 1995.

[3] Kolthoff, I.M., Chem Weekblad, "Application of hydrogen peroxide", Reference library, 17-197, 1920.

[4] Basett, J., Deniney, C.R., Jeffery, H.G. and Mendham, J., “Analysis of H2O2 oxidationreduction titration", Vogel text book quantitative inorganic analysis, fourth edition, 1978.

[5] Basett, J., Deniney, C.R., Jeffery, H.G. and Mendham, J., "Analysis of H2O2 oxidationreduction titration", Vogel text book quantitative inorganic analysis, fourth edition, 1978.

[6] Basett, J., Deniney, C.R., Jeffery, H.G. and Mendham, J., "Analysis of H2O2 oxidationreduction titration", Vogel text book quantitative inorganic analysis, fourth edition, 1978.

[7] Harber, F. and Weiss, J., "The catalytic decomposition of hydrogen peroxide by iron salts”, Proc. R .Soc. series, 134, 332 - 51, 1934.

[8] Muruganandham, M. and Swaminathan, M., "Decolourisation of reactive orange 4 by Fenton and Photo-Fenton oxidation technology", Dyes and pigments 63, 315-321, 2004.

[9] Muruganandham, M. and Swaminathan, M., "Decolourisation of reactive orange 4 by Fenton and Photo-Fenton oxidation technology", Dyes and pigments 63, 315-321, 2004.

[10] Sheng, H., Chi, M. and Horng, G., "Operating characteristic and kinetic studies of surfactant wastewater treatment by Fenton oxidation", Water research V33, 7, 1735 1741, 1999. 
[11] Sureyya, M. and Doniz, K., "Color and COD reduction from wastewater containing reactive black 5", Chemosphere, 54, 433-441, 2004.

[12] Dutta, K., Mukhopadhyah, S., Bhattacharjee, S. and Chaudhuri, B., "Chemical oxidation of methylene blue using Fenton - like reaction", J.hazard matter, B84, 57-71, 2001.

[13] Pala, A. and Erden, G., "Decolorization of a baker's yeast industry effluent by Fenton oxidation", Journal of Hazardous Materials, B127, 141-148, 2005.

[14] Shyh Fang Kang, Chih. Hsaing. Liao and Mon Chun Chen, "Preoxidation and coagulation of textile wastewater by the Fenton process", Chemosphere, 46, 923 - 928, 2002.

[15] Christine A. Murray and Simon A. parsons, "Removal of NOM from drinking water: Fenton's and photo Fenton's process", Chemosphere, 54, 1017-1023, 2004.

[16] Fares Al Momani, Carmen Sans and Santiago Esplugas, "A comparative study of the advanced oxidation of 2,4-dichlorophenol", Journal of hazardous materials, 107, 123$129,2004$.

[17] Hu Chun, Wang Yizhong "Decolorization and biodegradability of photocatalytic treated azo dyes and wool textile wastewater", Chemosphere, V39, 12, 2107-2115, 1999.

[18] Julia Garcý'a-Montaño, Francesc Torrades, Jose' A. Garcý'a-Hortal, Xavier Dome`nech, Jose' Peral "Combining photo-Fenton process with aerobic sequencing batch reactor for commercial hetero-bireactive dye removal", Applied Catalysis B: Environmental 67, 86-92, 2006. 


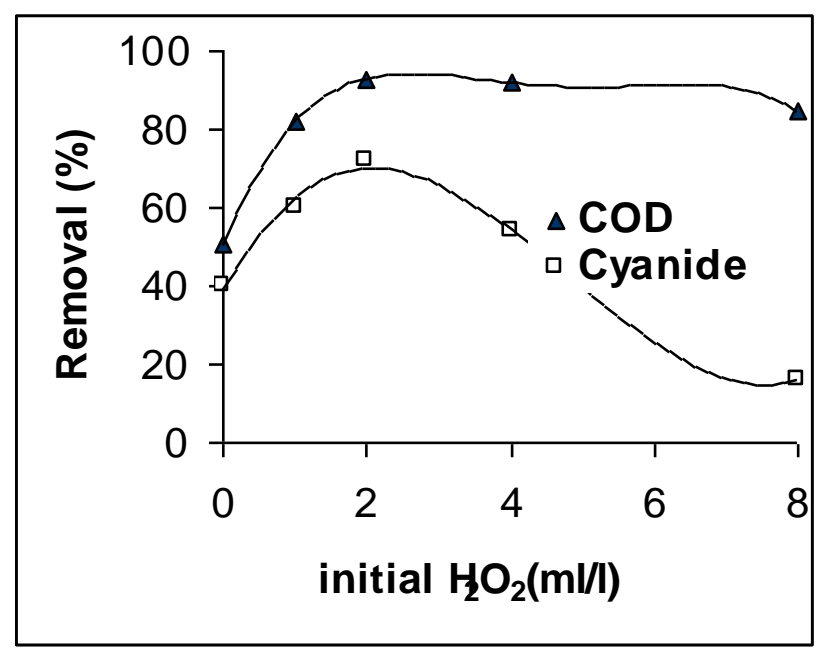

Figure 1: Effect of different $\mathrm{H}_{2} \mathrm{O}_{2}$ concentrations on removal efficiency $\left(\mathrm{COD}_{0}=16660 \mathrm{mg} / \mathrm{l}, \mathrm{CN}_{0}^{-}=9.11 \mathrm{mg} / \mathrm{l}, \mathrm{Time}=60 \mathrm{~min}, \mathrm{Temp}=25^{\mathrm{O}} \mathrm{C}, \mathrm{pH}=3\right.$

$\left.\mathrm{Fe}^{2+}=402 \mathrm{mg} / \mathrm{l}\right)$

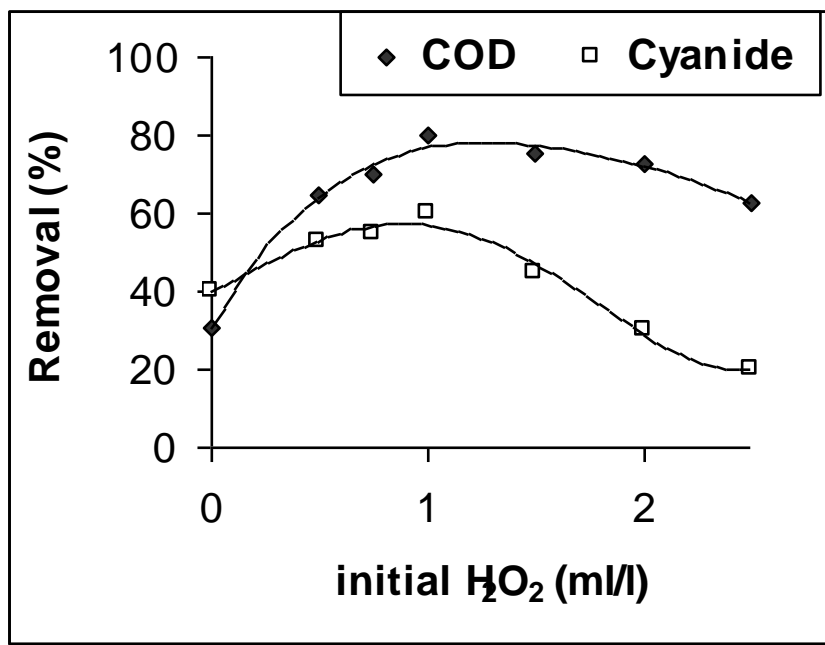

Figure 3: Effect of $\mathrm{H}_{2} \mathrm{O}_{2}$ concentration on removal efficiency (FLP,RW)

$\left(\mathrm{COD}_{\mathrm{O}}=16660 \mathrm{mg} / \mathrm{l}, \mathrm{CN}_{\mathrm{O}}^{-}=9.11 \mathrm{mg} / \mathrm{l}\right.$ $\mathrm{pH}=3$, Time $=60 \mathrm{~min}, \mathrm{Fe}^{3+}=20.7 \mathrm{mg} / 1$ Temp $=25{ }^{\mathrm{O}} \mathrm{C}$ )

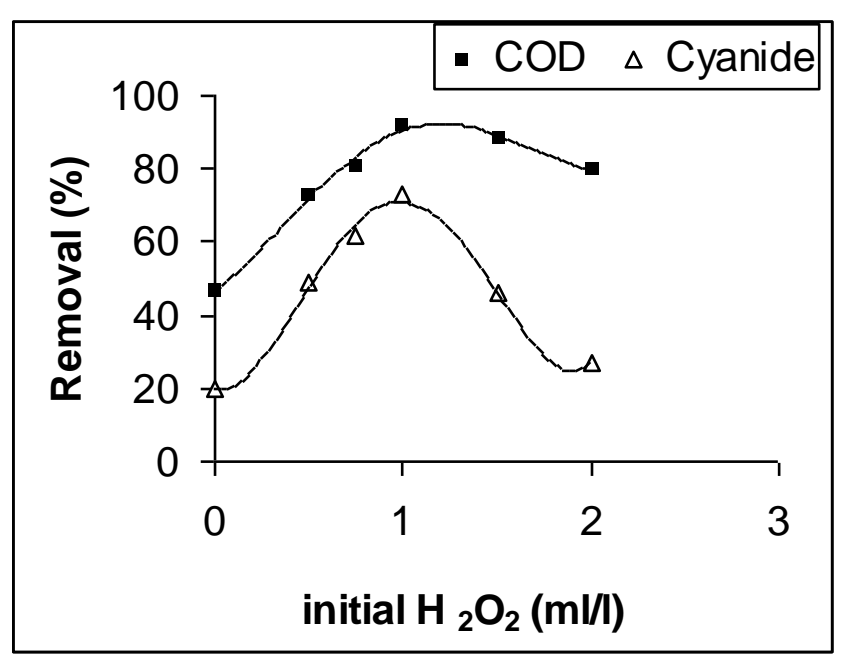

Figure (2): Effect of low $\mathrm{H}_{2} \mathrm{O}_{2}$ concentration on removal efficiency $(\mathrm{FP}, \mathrm{RW})\left(\mathrm{Temp}=25^{\mathrm{O}} \mathrm{C}\right.$, $\left(\mathrm{COD}_{0}=16660 \mathrm{mg} / \mathrm{l}, \mathrm{Fe}^{2+}=20 \mathrm{mg} / \mathrm{l}\right)$ $\mathrm{CN}^{-}=9.11 \mathrm{mg} / \mathrm{l}$, Time $\left.=60 \mathrm{~min}\right)$ 


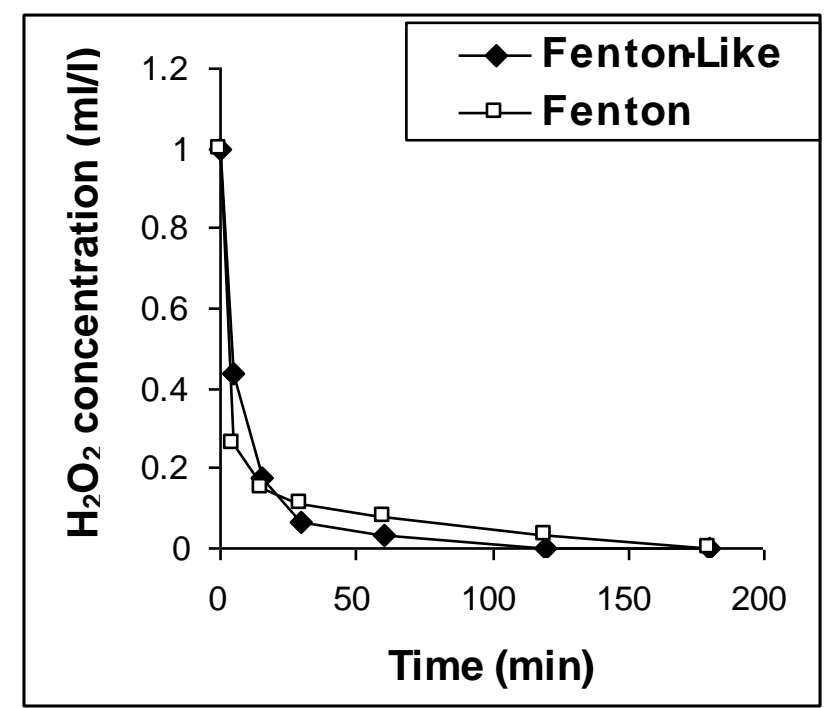

Figure 5: Comparative consumption of $\mathrm{H}_{2} \mathrm{O}$, by time at $45^{\mathrm{O}} \mathrm{C}$ by both (FP and FLP) $\left(\mathrm{COD}_{0}=16660 \mathrm{mg} / \mathrm{l}, \mathrm{CN}^{-}=9.11 \mathrm{mg} / \mathrm{l}\right.$ $\left.\mathrm{pH}=3, \mathrm{Fe}^{2+}=20 \mathrm{mg} / \mathrm{l}, \mathrm{Fe}^{3+}=20.7 \mathrm{mg} / \mathrm{l}\right)$

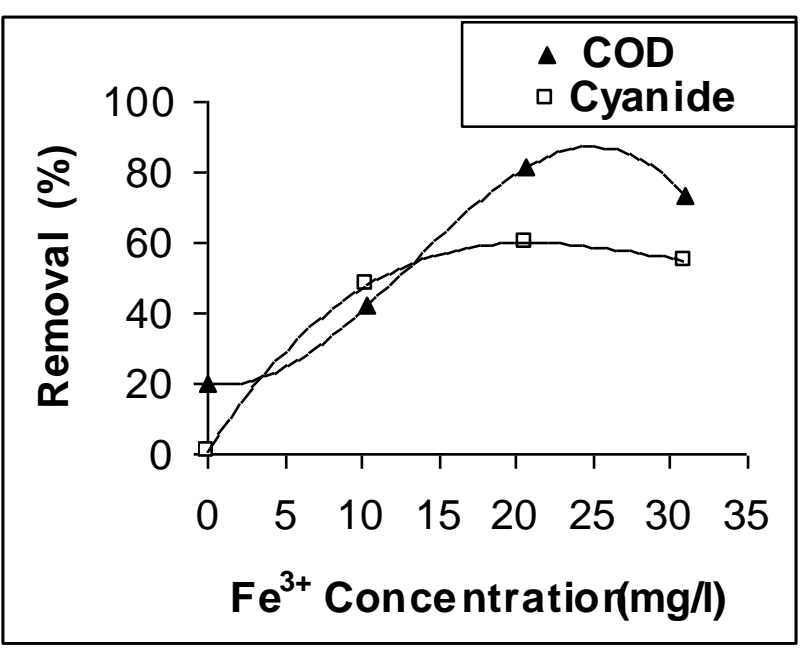

Figure 7: Effect of $\mathrm{Fe}^{3+}$ dose on removal Efficiency (FLP) $\left(\mathrm{COD}_{\mathrm{O}}=16660 \mathrm{mg} / \mathrm{l}, \mathrm{pH}=3\right.$ $\mathrm{CN}_{\mathrm{O}}^{-}=9.11 \mathrm{mg} / \mathrm{l}, \mathrm{Temp} .=25^{\mathrm{O}} \mathrm{C}, \mathrm{H}_{2} \mathrm{O}_{2}=1 \mathrm{ml} / 1$ Time $=60 \mathrm{~min}$ )

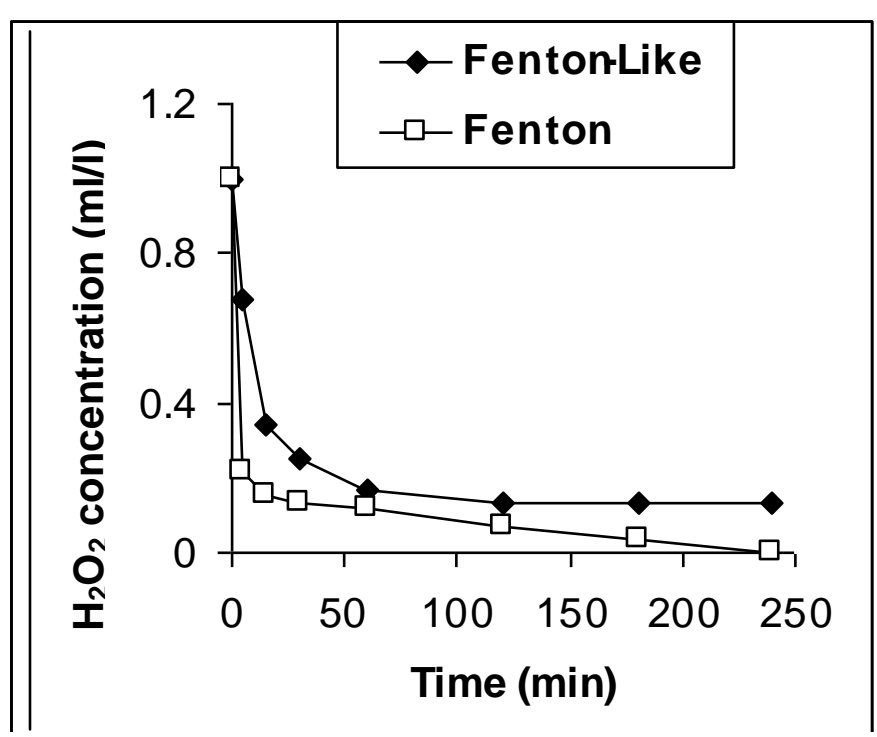

Figure 4: Comparative consumption of $\mathrm{H}_{2} \mathrm{O}_{2}$ by time at $25^{\circ} \mathrm{C}$ by both (FP and FLP).

$\mathrm{CN}_{0}^{-}=9.11 \mathrm{mg} / \mathrm{l}, \mathrm{pH}=3, \mathrm{Fe}^{2+}=20 \mathrm{mg} / \mathrm{l}$ $\mathrm{COD}_{0}=16660 \mathrm{mg} / \mathrm{l}, \mathrm{Fe}^{3+}=20.7 \mathrm{mg} / \mathrm{l}$

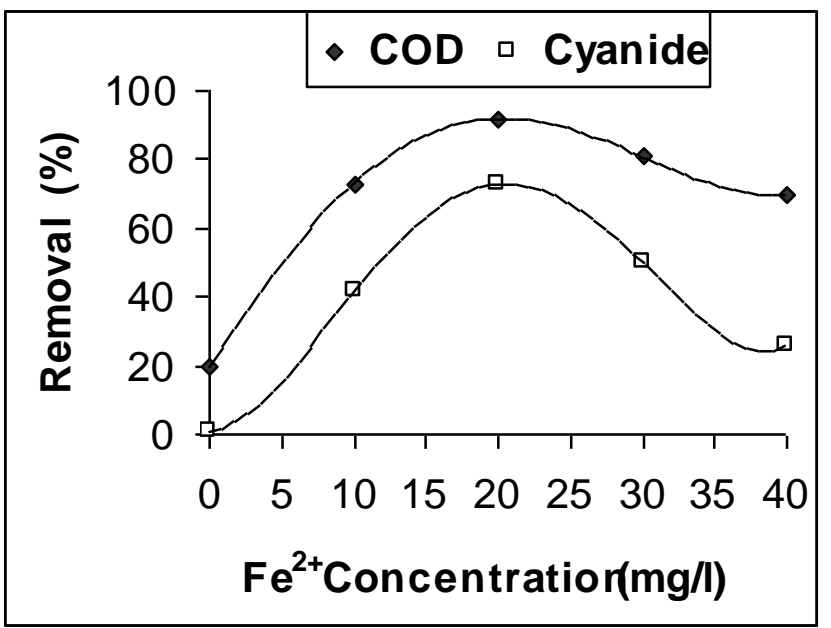

Figure 6: Effect of $\mathrm{Fe}^{2+}$ dose on removal efficiency, $\left(\mathrm{Fe}^{2+}=20 \mathrm{mg} / \mathrm{l}\right.$, $\mathrm{CN}^{-}=9.11 \mathrm{mg} / 1, \mathrm{pH}=3$,

Temp. $=25^{\circ} \mathrm{C}, \quad \mathrm{COD}_{\mathrm{O}}=16660 \mathrm{mg} / \mathrm{l}$, $\mathrm{H}_{2} \mathrm{O}_{2}=1 \mathrm{ml} / \mathrm{l}$, Time $\left.=60 \mathrm{~min}\right)$ 


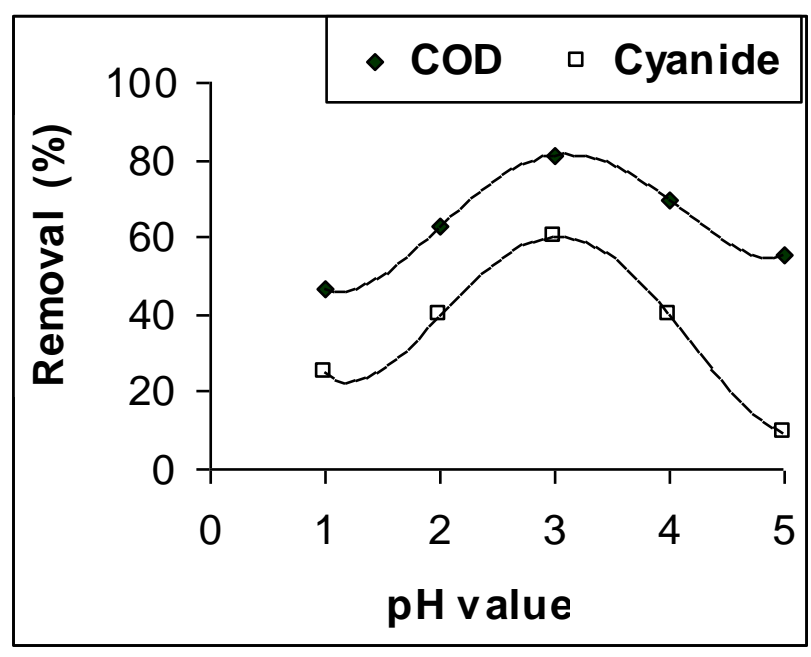

Figure 9: Effect of $\mathrm{pH}$ values on removal efficiency (FLP) $\left(\mathrm{H}_{2} \mathrm{O}_{2}=1 \mathrm{ml} / \mathrm{l}\right.$, Time $=60 \mathrm{~min}$ $\mathrm{Temp}=25^{\mathrm{O}} \mathrm{C}, \mathrm{COD}_{\mathrm{O}}=16660 \mathrm{mg} / \mathrm{l}$,

$\left.\mathrm{CN}^{-}=9.11 \mathrm{mg} / \mathrm{l}, \mathrm{Fe}^{3+}=20.7 \mathrm{mg} / \mathrm{l}\right)$

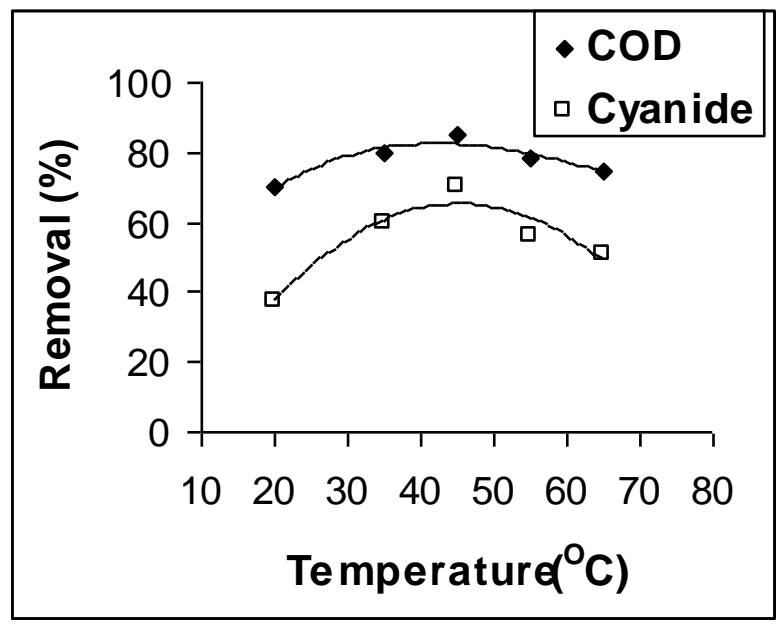

Figure 10: Effect of temperature on COD depression and cyanide removal efficiency for (FP) $\left(\mathrm{COD}_{\mathrm{O}}=16660 \mathrm{mg} / \mathrm{l}\right.$,

$\mathrm{CN}^{-} \mathrm{O}=9.11 \mathrm{mg} / \mathrm{l}, \mathrm{Fe}^{2+}=20 \mathrm{mg} / \mathrm{l}$,

$\mathrm{H}_{2} \mathrm{O}_{2}=1 \mathrm{ml} / \mathrm{l}, \mathrm{pH}=3$, Time $=60 \mathrm{~min}$ )

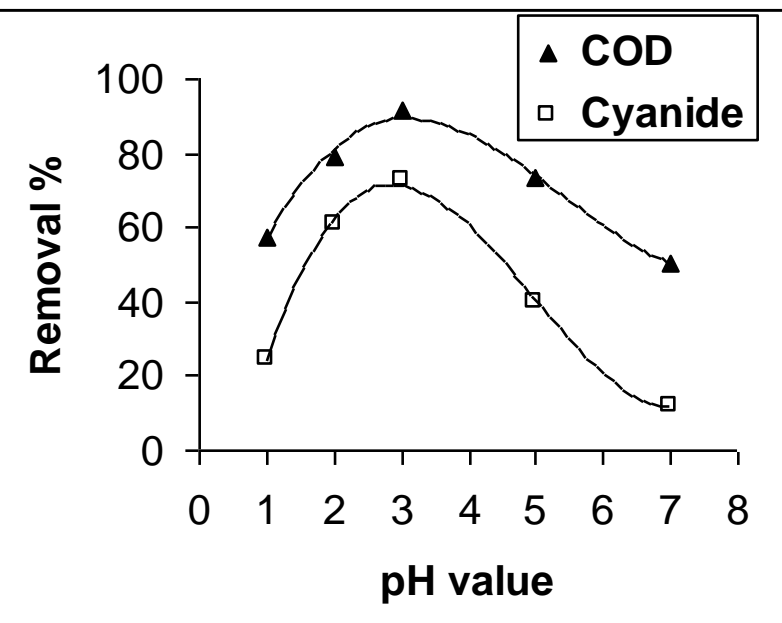

Figure 8: Effect of $\mathrm{pH}$ values on removal efficiency (FP)

$\left(\mathrm{COD}_{0}=16660 \mathrm{mg} / \mathrm{l}, \mathrm{CN}_{0}^{-}=9.11 \mathrm{mg} / \mathrm{l}\right.$ $\mathrm{Fe}^{2+}=20 \mathrm{mg} / \mathrm{l}$, Time $=60 \mathrm{~min}$

Temp. $=25^{\mathrm{O}} \mathrm{C}, \mathrm{H}_{2} \mathrm{O}_{2}=1 \mathrm{ml} / \mathrm{l}$ )

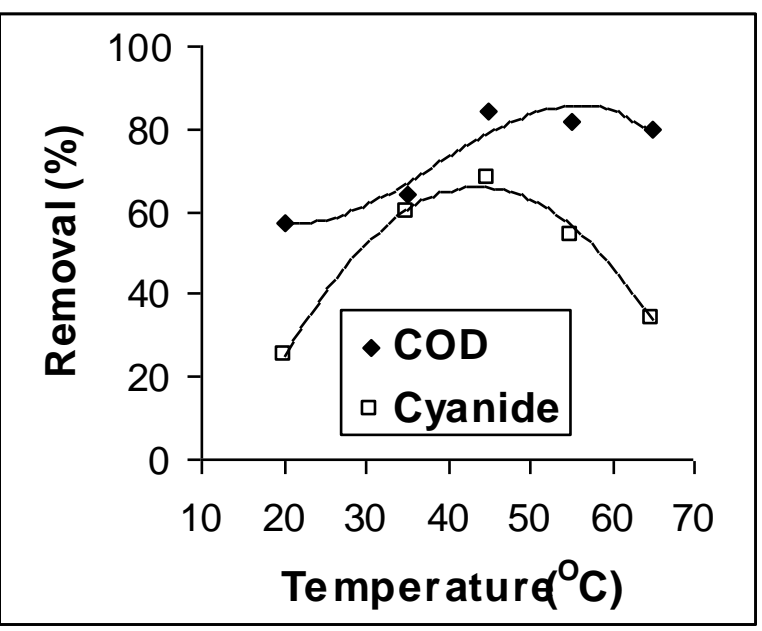

Figure 11: Effect of temperature on COD depression and cyanide removal efficiency for (FLP) $\left(\mathrm{COD}_{\mathrm{O}}=16660 \mathrm{mg} / \mathrm{l}\right.$,

$\mathrm{CN}^{-} \mathrm{O}=9.11 \mathrm{mg} / \mathrm{l}, \mathrm{Fe}^{3+}=20.7 \mathrm{mg} / \mathrm{l}$, $\mathrm{H}_{2} \mathrm{O}_{2}=1 \mathrm{ml} / \mathrm{l}, \mathrm{pH}=3$, Time $=60 \mathrm{~min}$ ) 


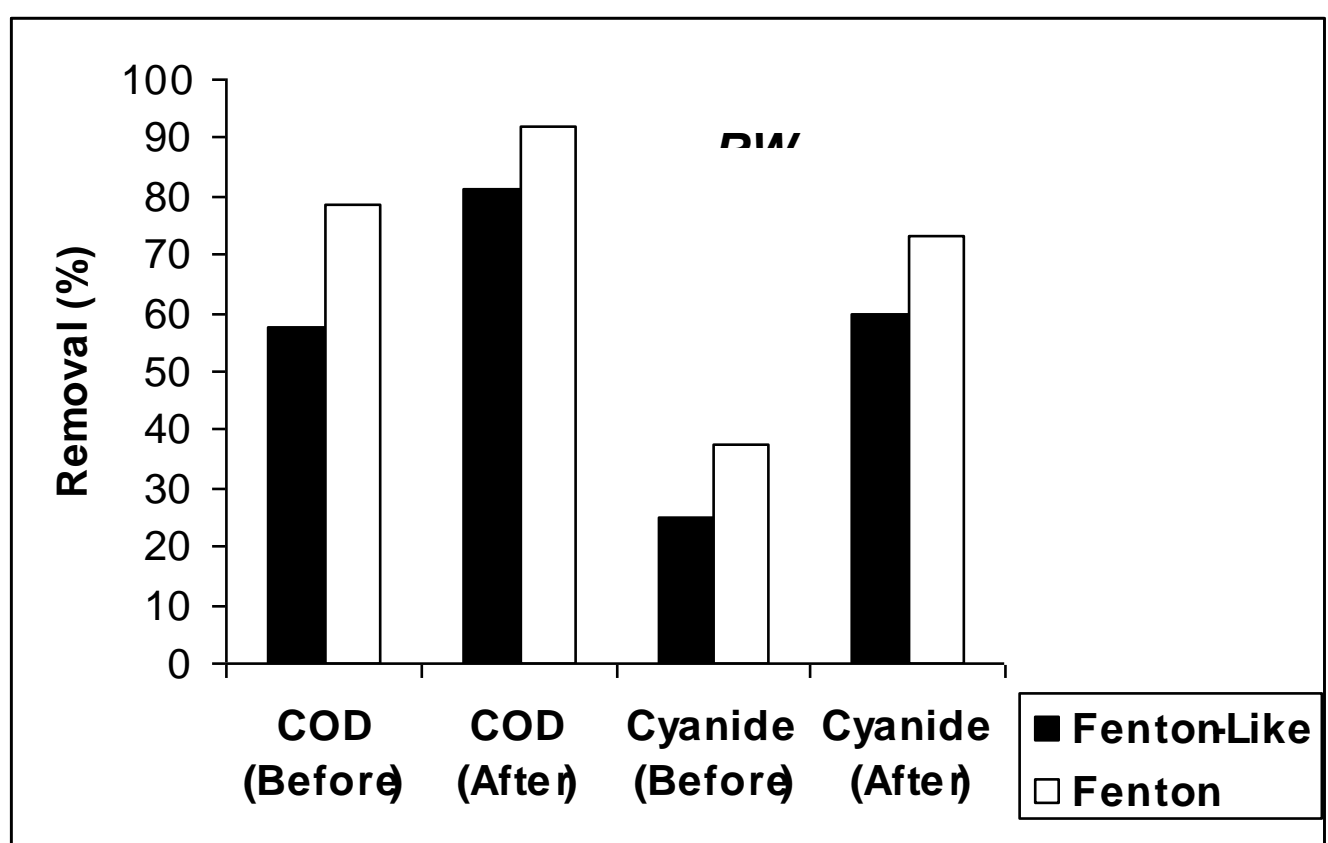

Figure 12: Effect of presence of free $\mathrm{H}_{2} \mathrm{O}_{2}$ after treatment $\left(\mathrm{Fe}^{3+}=20.7 \mathrm{mg} / \mathrm{l}\right.$ $\mathrm{H}_{2} \mathrm{O}_{2}=1 \mathrm{ml} / 1, \mathrm{Fe}^{2+}=20 \mathrm{mg} / \mathrm{l}, \mathrm{pH}=3$, Time $=60 \mathrm{~min}, \mathrm{COD}_{\mathrm{O}}=16660 \mathrm{mg} / \mathrm{l}$ $\left.\mathrm{CN}_{\mathrm{O}}^{-}=9.11 \mathrm{mg} / \mathrm{l}\right)$

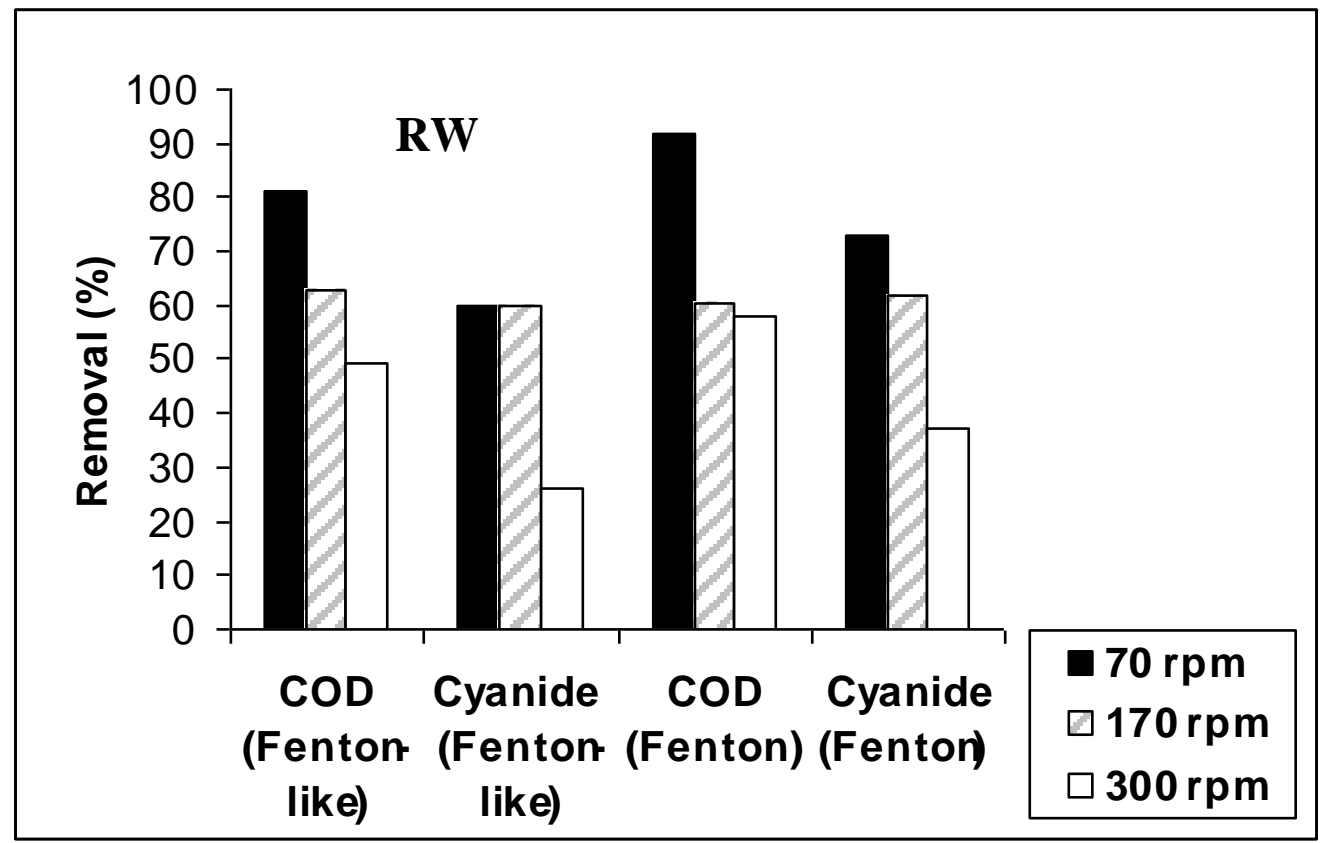

Figure 13: Effect of stirring on COD and cyanide removals $\left(\mathrm{Fe}^{3+}=20.7 \mathrm{mg} / 1\right.$ $\mathrm{H}_{2} \mathrm{O}_{2}=1 \mathrm{ml} / 1, \mathrm{Fe}^{2+}=20 \mathrm{mg} / \mathrm{l}, \mathrm{pH}=3$, Time $=60 \mathrm{~min}, \mathrm{COD}_{\mathrm{O}}=16660 \mathrm{mg} / \mathrm{l}$ $\left.\mathrm{CN}_{\mathrm{O}}^{-}=9.11 \mathrm{mg} / \mathrm{l}\right)$ 


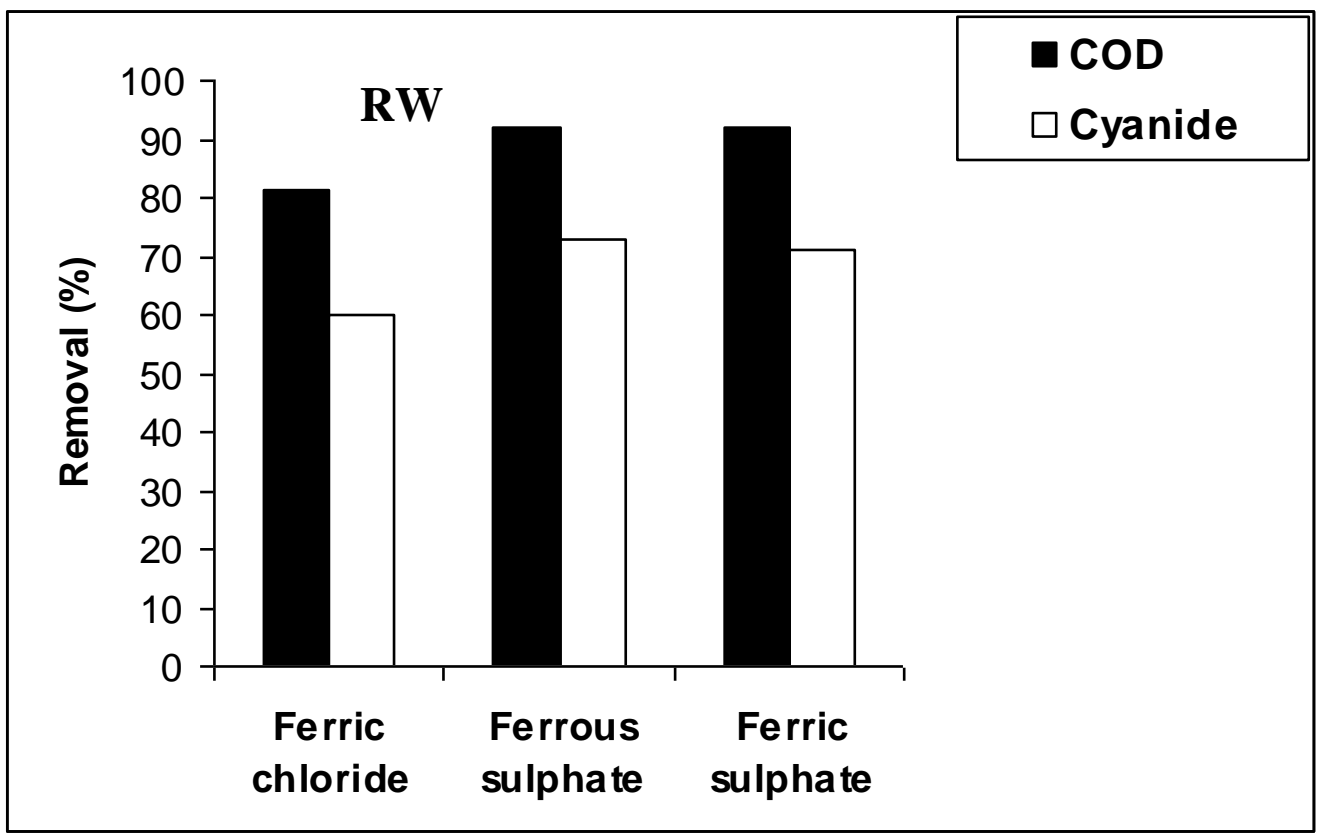

Figure 14: Effect of the type of catalyst on COD and cyanide removals. $\left(\mathrm{COD}_{\mathrm{O}}=16660 \mathrm{mg} / \mathrm{l}, \mathrm{CN}_{\mathrm{O}}^{-}=9.11 \mathrm{mg} / \mathrm{l}, \mathrm{pH}=3, \mathrm{H}_{2} \mathrm{O}_{2}=1 \mathrm{ml} / \mathrm{l}, \mathrm{Fe}^{2+}=20 \mathrm{mg} / \mathrm{l}\right.$, $\mathrm{Fe}^{3+}=20.7 \mathrm{mg} / \mathrm{l}$, Time $\left.=60 \mathrm{~min}\right)$

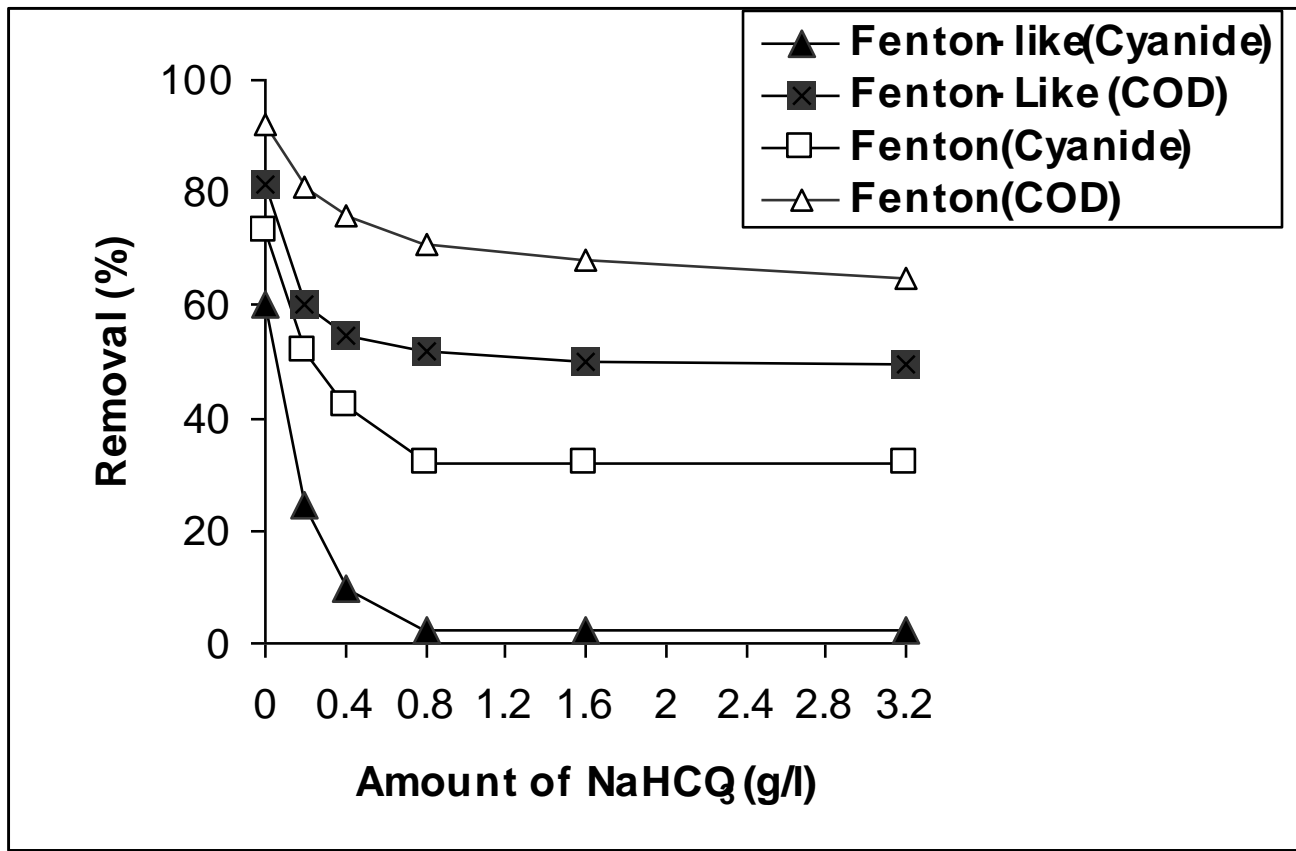

Figure 15: Effect of $\left(\mathrm{OH}^{\circ}\right)$ scavengers on COD and cyanide removals $\left(\mathrm{H}_{2} \mathrm{O}_{2}=1 \mathrm{ml} / 1, \mathrm{Fe}^{2+}=20 \mathrm{mg} / \mathrm{l}, \mathrm{pH}=3\right.$, Time $=60 \mathrm{~min}, \mathrm{Fe}^{3+}=20.7 \mathrm{mg} / \mathrm{l}$, $\left.\mathrm{CN}^{-}=9.11 \mathrm{mg} / \mathrm{l}, \mathrm{CODo}=16660 \mathrm{mg} / \mathrm{l}\right)$ 


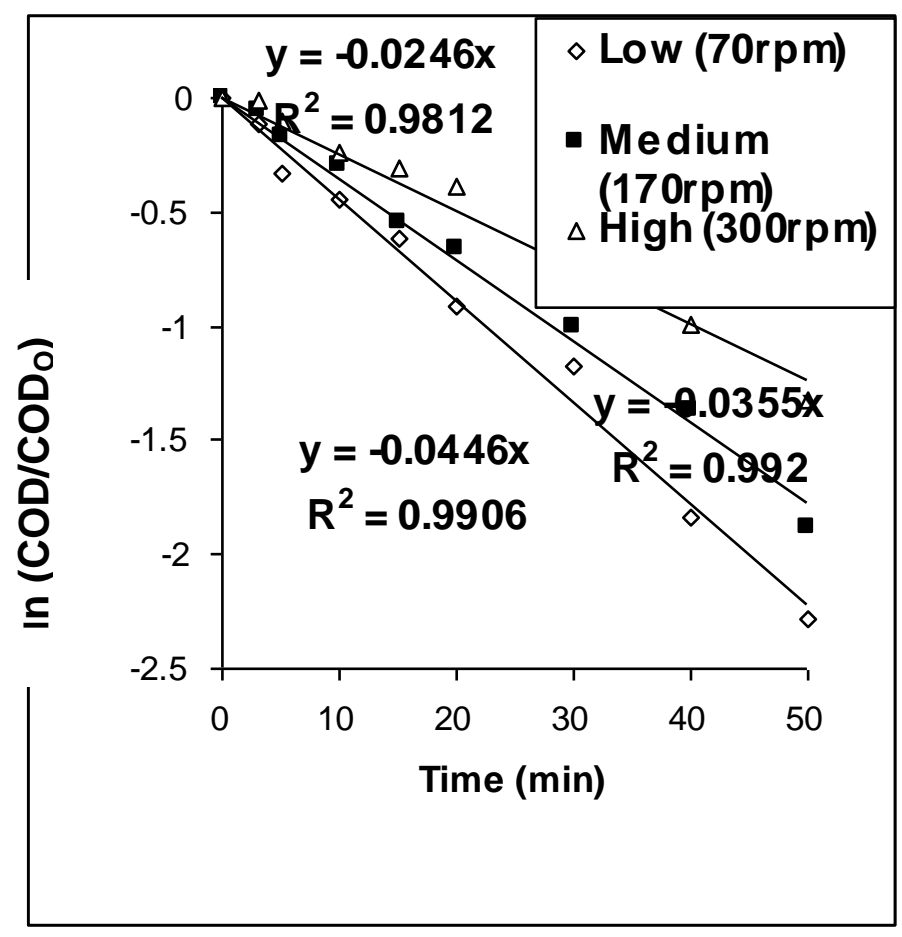

Figure 16: COD - Logarithmic dimensionless concentration change $(\mathrm{FP})\left(\mathrm{COD}_{\mathrm{O}}=2640 \mathrm{mg} / \mathrm{l}, \mathrm{pH}=3\right.$, $\mathrm{CN}^{-} \mathrm{O}=120 \mathrm{mg} / \mathrm{l},, \mathrm{Fe}^{2+}=60 \mathrm{mg} / \mathrm{l}$, Temp. $=25^{\mathrm{O}} \mathrm{C}, \mathrm{H}_{2} \mathrm{O}_{2}=4 \mathrm{ml} / \mathrm{l}$ )

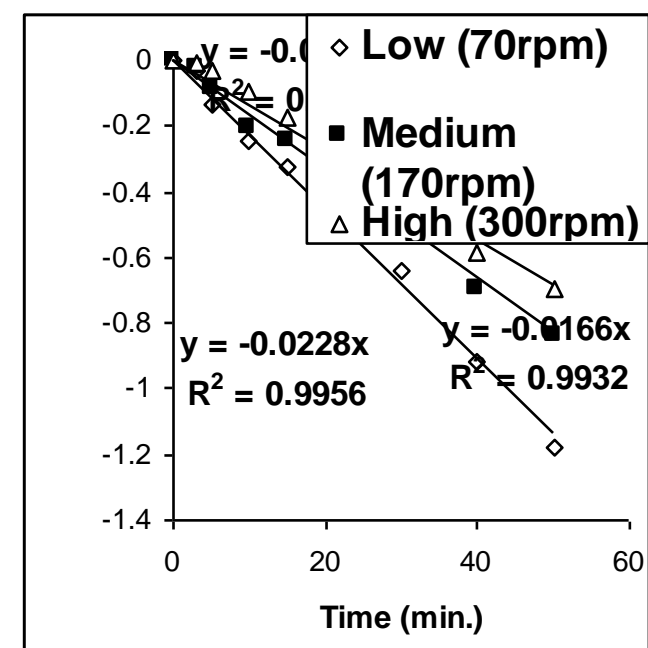

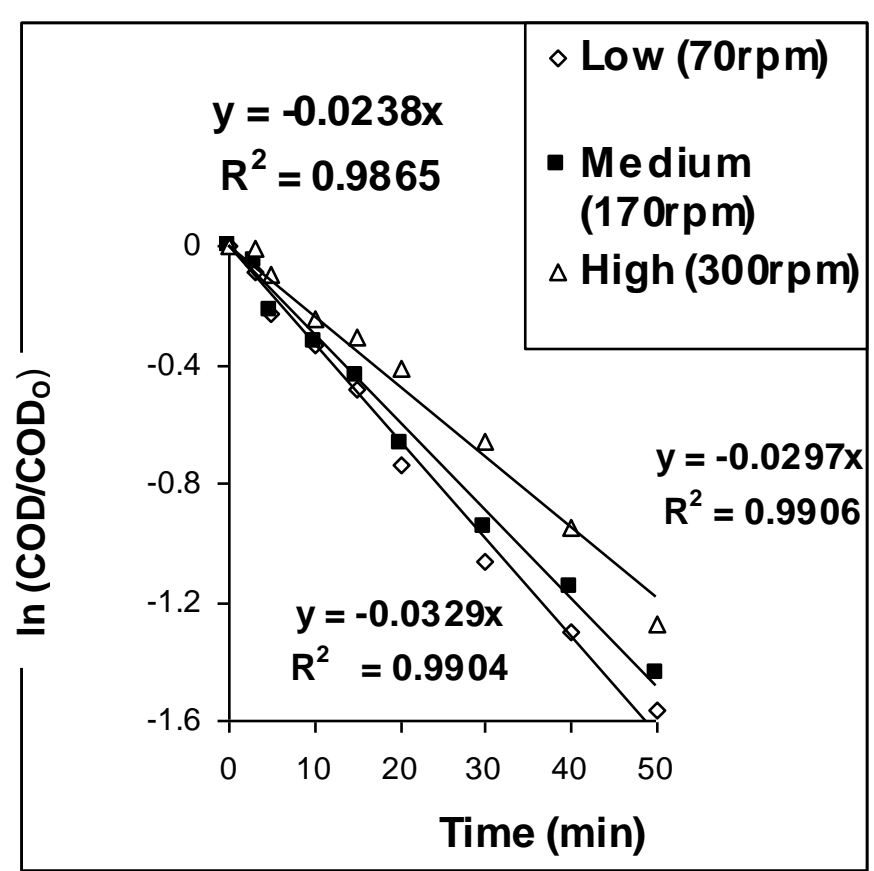

Figure (17): COD - Logarithmic dimensionless concentration change (FLP) $\left(\mathrm{COD}_{\mathrm{O}}=2640 \mathrm{mg} / \mathrm{l}, \mathrm{pH}=3, \mathrm{CN}^{-} \mathrm{o}=120 \mathrm{mg} / \mathrm{l}\right.$, $\mathrm{Fe}^{3+}=62 \mathrm{mg} / \mathrm{l}$., $\mathrm{H}_{2} \mathrm{O}_{2}=4 \mathrm{ml} / \mathrm{l}$, Temp. $=25^{\mathrm{O}} \mathrm{C}$ )

Figure 18)Cyanide - Logarithmic

dimensionless concentration change (FP)

$\left(\mathrm{COD}_{\mathrm{O}}=2640 \mathrm{mg} / \mathrm{l}, \mathrm{CN}_{\mathrm{O}}^{-}=120 \mathrm{mg} / \mathrm{l}\right.$,

$\mathrm{H}_{2} \mathrm{O}_{2}=4 \mathrm{ml} / \mathrm{l}$, Temp. $\left.=25^{\circ} \mathrm{C}, \mathrm{Fe}^{2+}=60 \mathrm{mg} / \mathrm{l}\right)$ 


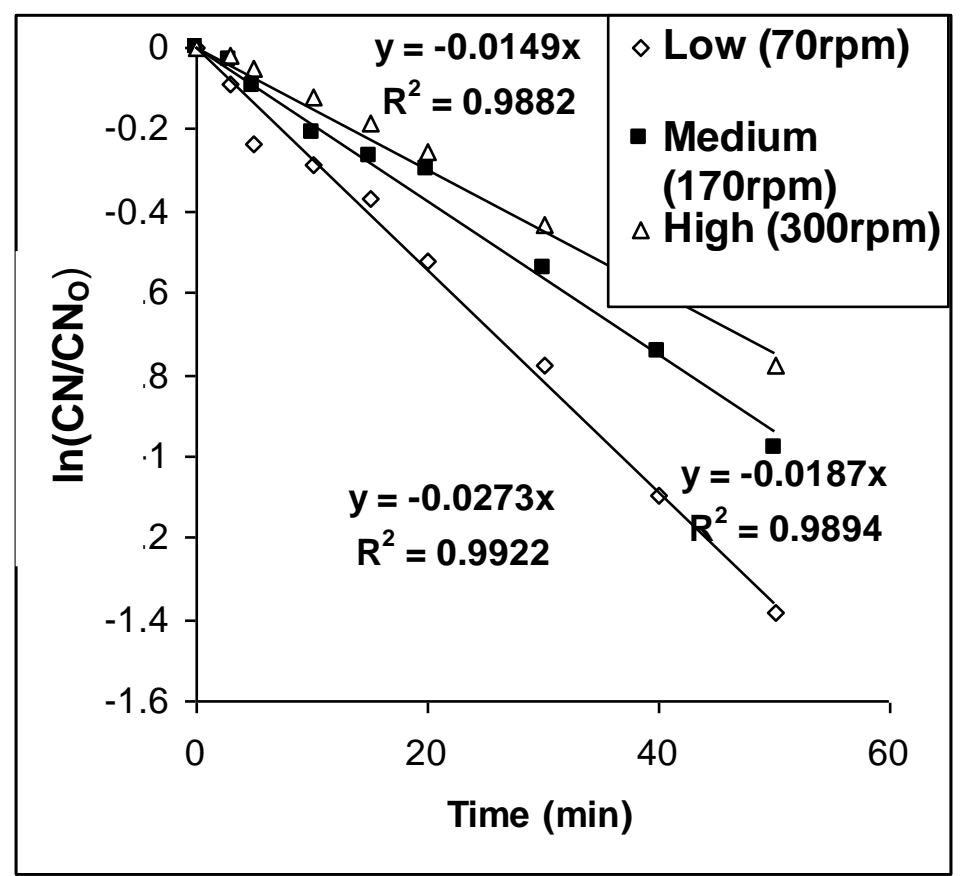

Figure 19 Cyanide - Logarithmic

dimensionless concentration change (FLP)

$\mathrm{COD}_{\mathrm{O}}=2640 \mathrm{mg} / \mathrm{l}, \mathrm{b} \mathrm{CN}_{\mathrm{O}}^{-}=120 \mathrm{mg} / \mathrm{l}$,

$\mathrm{H}_{2} \mathrm{O}_{2}=4 \mathrm{ml} / \mathrm{l}$. Temn $.=25^{\mathrm{O}} \mathrm{C} . \mathrm{Fe}^{3+}=62 \mathrm{mg} / \mathrm{l}$

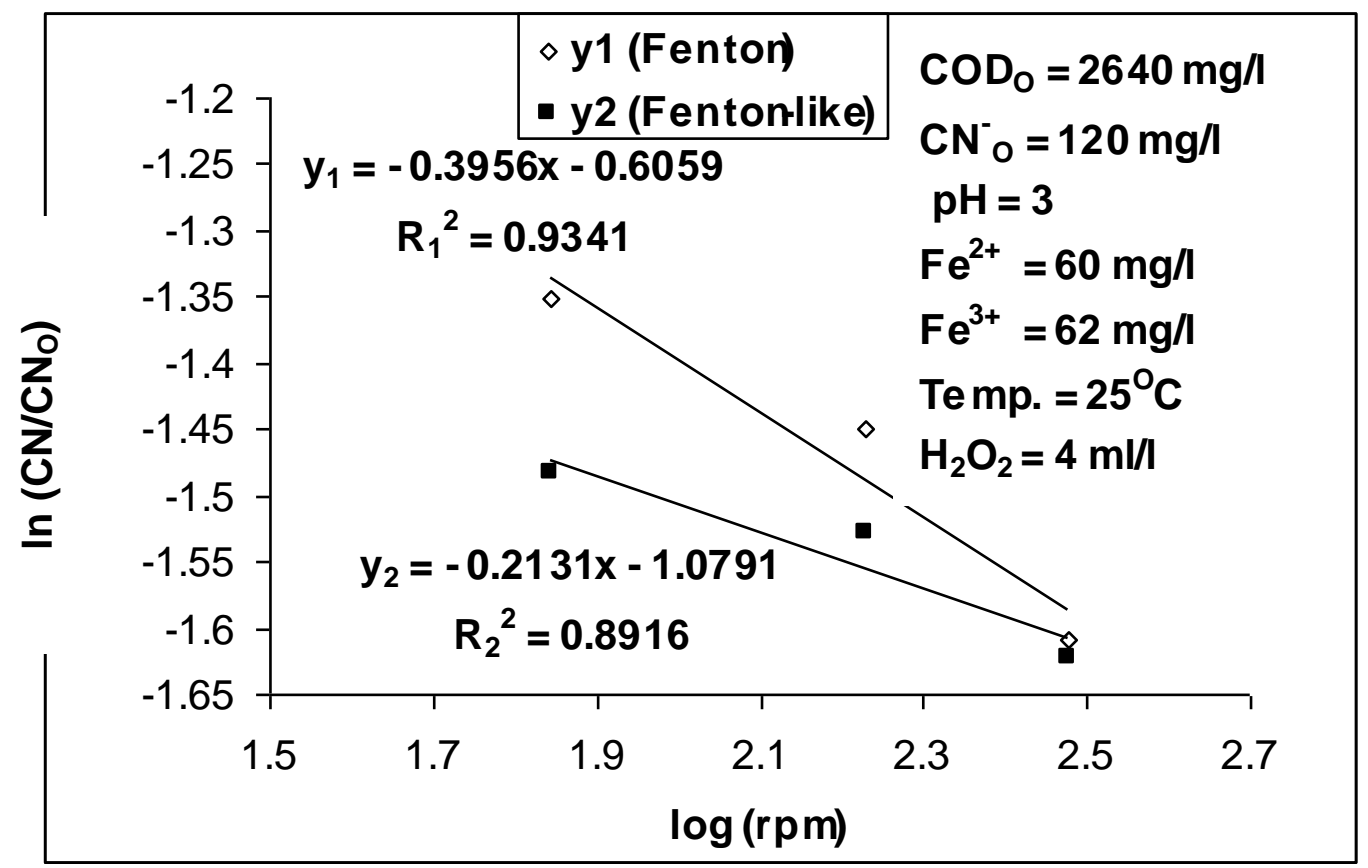

Figure 20: Log Ko versus log rpm for COD changes 


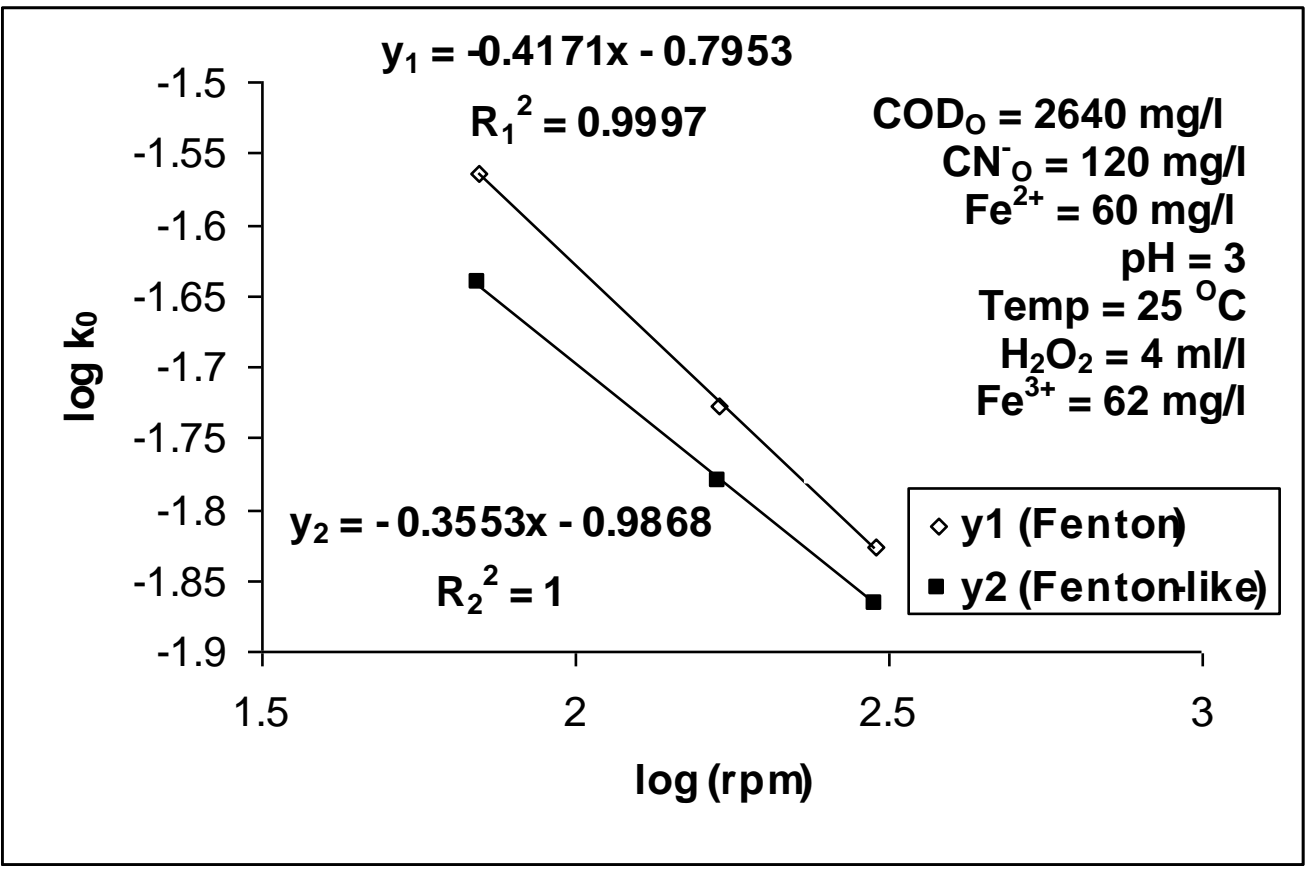

Figure 21: $\log \mathrm{K}_{\mathrm{o}}$ versus $\log$ rpm for cyanide removal

Table 1: Characteristics of the investigated real wastewater (RW)

\begin{tabular}{|c|c|c|c|}
\hline \multirow{2}{*}{ Parameter $(\mathrm{ppm})$} & \multicolumn{3}{|c|}{ Periodical effluent types (Averages) } \\
\cline { 2 - 4 } & $(6$ months $)$ & $\begin{array}{c}(15 \text { days }+ \\
\text { heavy oils })\end{array}$ & $\begin{array}{c}(15 \text { days }+ \\
\text { light oils })\end{array}$ \\
\hline COD & 2000 & 16660 & 6634 \\
\hline $\mathrm{CN}$ & 8.7 & 9.11 & 9 \\
\hline Oils & 4000 & 32910 & 23000 \\
\hline $\mathrm{pH}$ & 6.6 & 6.6 & 6.6 \\
\hline $\mathrm{T} . \mathrm{S} . \mathrm{S}$ & 400 & 6910 & 4208 \\
\hline $\mathrm{BOD}_{5}$ & 450 & 2500 & 800 \\
\hline $\mathrm{TOC}^{\mathrm{Cu}}$ & 700 & 6000 & 2600 \\
\hline $\mathrm{Cr}^{++}(\mathrm{VI})^{+}$ & 0.114 & 0.11 & 0.2 \\
\hline $\mathrm{Ni}^{++}$ & 0.3 & 0.13 & 0.215 \\
\hline & 0.85 & 0.4 & 0.6 \\
\hline
\end{tabular}

Table 2: Optimum operating conditions for realwastewater treatments

\begin{tabular}{|c|c|}
\hline Parameters & Values \\
\hline $\mathrm{H}_{2} \mathrm{O}_{2}$ & $1150 \mathrm{mg} / \mathrm{l}$ \\
\hline FeSO $_{4} 7 \mathrm{H}_{2} \mathrm{O}$ & $100 \mathrm{mg} / \mathrm{l}$ \\
\hline Reaction time & $300 \mathrm{~min}$ \\
\hline $\mathrm{PH}$ & 3 \\
\hline Temperature & $45^{\circ} \mathrm{C}$ \\
\hline Speed of Agitator & $70 \mathrm{rpm}$ \\
\hline COD & $16660 \mathrm{mg} / \mathrm{l}$ \\
\hline
\end{tabular}


Table 3: Total cost for treating one $\mathrm{m}^{3}$ by the Fenton process

\begin{tabular}{|l|l|}
\hline Chemicals costs, $\mathrm{Na}_{2} \mathrm{CO}_{3}$ is used & $0.73 \mathrm{LE}$ \\
\hline Equipments costs & $11 \times 10^{-3} \mathrm{LE}$ \\
\hline Construction costs & $2.14 \times 10^{-4} \mathrm{LE}$ \\
\hline Total costs, $\mathrm{Na}_{2} \mathrm{CO}_{3}$ is used & $0.741 \mathrm{LE}$ \\
\hline
\end{tabular}


Military Technical College

Kobry El-Kobbah, Cairo, Egypt

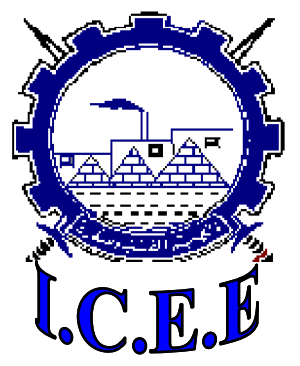

$5^{\text {th }}$ International Conference on

Chemical \& Environmental Engineering 25 - 27 May, 2010. 